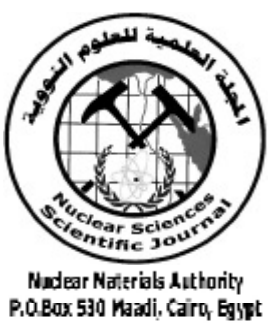

ISSN 2314-5609

Nuclear Sciences Scientific Journal

vol. 3, p 139 - 148

2014

\title{
EFFECT OF SOME PHYSICAL PROPERTIES OF THE BLACK SANDS ON THE RADIATION EXPOSURES AT MASTAROUH, NORTH NILE DELTA, EGYPT
}

\author{
YASSIN A. ABDEL-RAZEK; ABD EL-ALEEM A. ABU-DIAB and \\ ANTAR F. BAKHIT \\ Nuclear Materials Authority, P. O. 530 El Maadi
}

\begin{abstract}
The average apparent density of studied sediment is $1599 \mathrm{~kg} / \mathrm{m}^{3}$ and its effective porosity is 0.22 . The total heavy mineral contents in the black sands at Mastarouh area was found to vary from $10.56 \%$ to $39.66 \%$ with an average of $26.60 \%$. Its variation affects the activity concentrations of the four radio-nuclides, ${ }^{238} \mathrm{U}$, ${ }^{232} \mathrm{Th},{ }^{226} \mathrm{Ra}$, and ${ }^{40} \mathrm{~K}$, as well as the absorbed dose rate, radon flux and the total radioactivity. The mentioned variables display the same behavior like the total heavy minerals except ${ }^{232} \mathrm{Th}$. The averages of the activity concentration, in $\mathrm{Bq} / \mathrm{kg}$, for the four profiles due to the four radio-nuclides are: It is $61.75,47.64,34.99$ and 44.11 for ${ }^{238} \mathrm{U}$; $63.22,49.88,35.19$ and 33.06 for ${ }^{232} \mathrm{Th}$, and $42.28,37.6,18.5$ and 25.36 for $226 \mathrm{Ra}$. The measured activity concentration emitted from ${ }^{40} \mathrm{~K}$ was found to vary from not detected in the four profiles to maximum values of $187.70,97.03,63.73$ and 106.40 with the averages $63.50,55.40,37.56$ and 56.79, respectively. The minimum values for the total radioactivity in $\mathrm{Bq} / \mathrm{kg}$ for the four profiles are 118.00, 61.41, 49.06 and 85.94 while the adjacent maximum values are 340.20,24.40, 153.70 and 109.70. The radon gas concentration in $\mathrm{Bq} / \mathrm{kg}$ was found to vary from 111 to 2057 with an average of 1211 .

The measured dose values, in $\mathrm{nGy} / \mathrm{h}$, are generally less than the calculated values. The calculated ones vary from a minimum value of 20.50 to a maximum value of 111.00. About three quarters of the averages absorbed dose rate (D) are beyond the worldwide average absorbed dose rate. The average of the absorbed dose rate on the first profile, neighbor the shore line, is higher than the worldwide average then it decreases for the next three profiles to be less than the worldwide average. The radon flux at Mastarouh area has an average of $2.48 \times 10^{-3}\left(\mathrm{~Bq} \mathrm{~m}^{-2} \mathrm{~s}^{-1}\right)$ being much lower than the worldwide average. However, the radiation exposures at Mastarouh area are below the worldwide public exposures. The activity concentrations of all the studied radio-nuclides in the black sands due north from the North Africa International Highway at Mastarouh area are comparable to the typical worldwide concentrations.
\end{abstract}

\section{INTRODUCTION}

The Egyptian Black sands are considered one of the important mineral resources in Egypt. They contain six heavy economic minerals. Two of them are radioactive minerals, namely zircon and monazite besides traces of uranothorite and xenotime minerals (Zaghloul, 1959 \&1960 and Zaghloul et al.
1961, $1965 \&$ 1966). These heavy radioactive minerals exhibit radioactivity character to the Egyptian black sands. Though, it is used as a tracer in the exploration of the heavy minerals. Therefore, ground radiometric as well as air born surveys were conducted on these black sands to delineate the anomalous concentration of the heavy minerals as black sand lenses (Wassef 1973; Meleik et. al., 1978). 
Also, some studies concerning the radioactive emanation of these sediments and its impact on the inhabitant through air were done on Abu Khashaba beach where the main heavy mineral concentration as well as the physical dressing pilot plant of the beach sands were studied (Barakat 2008; Abdel-Razek et. al., 2012 and Nasr, 2012).

In fact, Mastarouh village is located neighboring Kom Mastarough, on the coastal plain, at nearly the midpoint of Rosetta-El Burullus Lake inlet. Also, the North Africa International Highway traverses the coastal plain in its southern region (Fig., 1). The area is subjected to many developments and resident projects. Despite this fact, this area lacks any previous study dealing with the impact of the emanated radioactivity from of the black sand deposit on the inhabitant and the passenger on the road. Therefore, it is necessary to study the radiation exposure due to the radioactive elements and its relationships with the physical properties of the black sand like, the porosity, the water content, the apparent specific gravity and the heavy mineral content of the sediments, which affect the exposure rate.

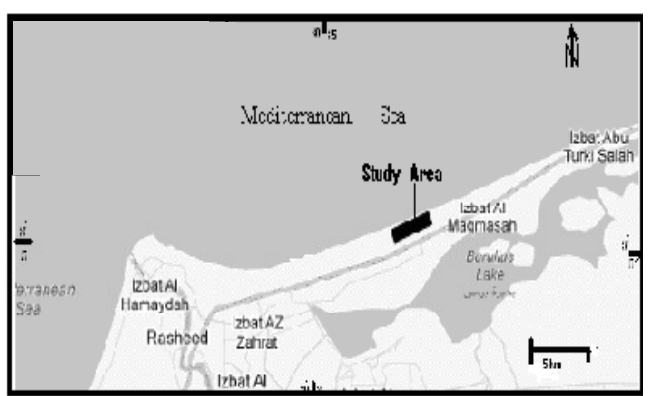

Fig. 1: Location map of the studied area

To perform the present investigation about $10 \mathrm{~km} 2$ (Long. $30^{\circ} 32^{\prime}-30^{\circ} 38^{\prime} \mathrm{E}$ and Lat. $31^{\circ}$ $26^{\prime}-31^{\circ} 29^{\prime}$ N) neighboring Kom Mastarouh are subjected to sample collection, measuring the field radioactivity and the concentration of the radon gas in the sediment. The heavy minerals content, the porosity and the $\mathrm{U}, \mathrm{Th}, \mathrm{Ra}$ \& K content should be measured in the laboratory on the collected samples.

\section{METHODES AND TECHNIQUES}

\section{Field Work}

\section{Sampling}

The study area was subjected for 27 samples collection on a rectangular beach area $(2 \mathrm{~km} \mathrm{X} 5 \mathrm{~km})$ along four parallel profiles and also nearly parallel to North Africa International High Way. The grid pattern was 500X700m, Fig. (2). Each sample was taken by removing the wind laid sand on the surface of the deposit, then a small square trench of side $30 \mathrm{~cm}$ and a depth of $10 \mathrm{~cm}$ which represent the actual depth of the possible radiation from the deposit to the air.

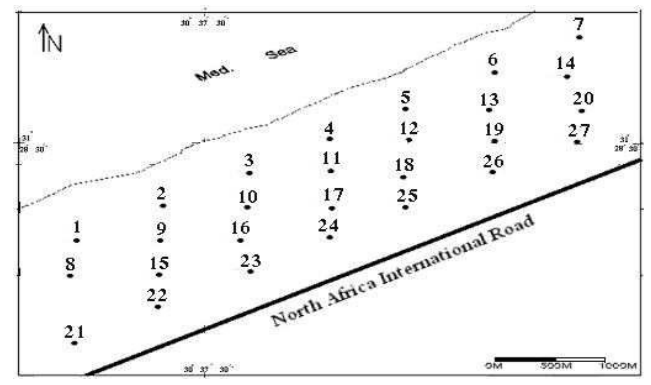

Fig. 2: Map shows the samples locations at Mastarouh

\section{Measurement of the water content and the radon gas concentrations inside the sands}

The fourth profile only which neighbor the highway was re-sampled to measured the emitted radon gas from the sediment because the water table in the other three profiles is shallower than the necessary depth for measuring the radon gas. This is done by digging a borehole $(3 \mathrm{~cm}$ diameter) applying a hand auger to a depth of $65 \mathrm{~cm}$ representing the studied thickness of the deposit. Each collected sample from each borehole was directly weighed at its collection then dried at $109{ }^{\circ} \mathrm{C}$ till all its water content was evaporated and weighed after cooling. The difference between the original and final weight of the sample was divided by its original weight. The results are shown in Table (1) representing the water content (W) in the sand sample 
Table 1 :Measured radon gas concentration $\left(\mathrm{C}_{\mathrm{Rn}}\right)$ , water content $(\mathrm{W})$ and the effective dose rate $(\mathrm{En})$ at the fourth profile

\begin{tabular}{lrrr}
\hline Sp. No. & W & $\begin{array}{r}\mathbf{C}_{\mathbf{R n}} \\
\left(\mathrm{Bq} / \mathbf{m}^{\mathbf{3}}\right)\end{array}$ & $\begin{array}{r}\mathbf{E} \\
(\mathrm{nSv} / \mathrm{h})\end{array}$ \\
\hline 21 & $\mathbf{0 . 1}$ & $\mathbf{1 1 1}$ & 7 \\
22 & $\mathbf{0 . 0 9}$ & $\mathbf{1 2 6 3}$ & $\mathbf{3 7}$ \\
23 & $\mathbf{0 . 0 9}$ & $\mathbf{1 7 8 2}$ & $\mathbf{3 7}$ \\
24 & $\mathbf{0 . 1}$ & $\mathbf{2 0 5 7}$ & $\mathbf{2 2}$ \\
25 & $\mathbf{0 . 1 2}$ & 1369 & 37 \\
26 & $\mathbf{0 . 1 1}$ & 975 & 7 \\
27 & $\mathbf{0 . 0 9}$ & 917 & 37 \\
Av. & 0.1 & 1211 & 26 \\
\hline
\end{tabular}

Also, each resultant borehole was used for measuring the concentration of the radon gas emanated from the sediment. This was done by inserting a soil probe into the borehole and the borehole was tightly closed for an hour. The soil probe was connected to a SARAD radon monitor through a filter to withdraw a sample from the air inside the hole. Radon gas concentration $(\mathrm{Bq} / \mathrm{m} 3)$ in each hole was displayed on the radon monitor after one hour. The concentration of radon gas builds up inside the hole according to the formula given by Tompkins (1978). The results are shown in Table (1).

$$
\mathrm{C}_{\mathrm{Rn}}(\mathrm{t})=(\mathrm{J} * \mathrm{~A} / \mathrm{V}) *\left(1-\mathrm{e}^{-\lambda \mathrm{t}}\right) / \lambda \ldots \ldots \ldots . .(1)
$$

Where $\mathrm{C}_{\mathrm{Rn}}=$ radon concentration inside the hole, $\left(\mathrm{Bq} / \mathrm{m}^{3}\right)$, $\mathrm{J}=$ radon flux, $\left(\mathrm{Bq} \mathrm{m}^{-2} \mathrm{~s}^{-1}\right), \mathrm{t}=$ time between digging and sampling, (s), $\mathrm{A}=$ side area of the hole, $\left(\mathrm{m}^{2}\right), \mathrm{V}=$ volume of the hole, $\left(\mathrm{m}^{3}\right), \lambda=$ radon decay constant, $\left(\mathrm{s}^{-1}\right)$.

\section{Measurement of the external effective dose over the sands}

The effective dose rates $(\mu \mathrm{Sv} / \mathrm{h})$ due to $\gamma$-ray exposures are measured at $1 \mathrm{~m}$ over the sands at each monitoring station along the fourth profile, using ALNOR RDS-100 gamma survey meter calibrated against a ${ }^{60} \mathrm{Co}$ $\gamma$-source of activity $7.4 \times 10^{8} \mathrm{~Bq}$ at the $\mathrm{Na}$ tional Institute of Standards and Technology (NIST). To obtain the effective dose rate (E) due to the emitted $\gamma$-rays from the radioactive elements in the soil sands only, the dose rate from the cosmic rays at sea level, which is 31
(nSv/h), (UNSCEAR 2000), was subtracted from the recorded readings. The results are shown in Table (1).

\section{Laboratory Work}

The obtained dry samples were subjected to quartering in order to obtain three representative samples one for heavy minerals evaluation weighing about $50 \mathrm{gm}$. The weight of the second one is about $100 \mathrm{gm}$ measuring both the apparent specific gravity and the porosity of the sand. While, the third representative sample weighing about $350 \mathrm{gm}$ will be used for radiometric measurements of the four radio-elements in the laboratory.

\section{Apparent density and porosity}

The apparent density and the porosity of the sand measured only for the borehole samples of profile four as they needed in the calculation of the radon flux. To conduct the measurement, each prepared representative sample weighing about $100 \mathrm{gm}$ was weighed and put in a graduated cylinder and thoroughly shaked to completely compact the detritus of the sediment inside the cylinder to approach the natural compactness. The volume of the sample was taken from the cylinder graduation. The apparent density $\left(\rho\right.$ in $\mathrm{kg} / \mathrm{m}^{3}$ ) for each sample was calculated by dividing the weight of each sample on its volume. The results are shown in Table (2) and are in harmony with the results given by Dabbour (1992) and Barakat (2004).

Table 2 : Apparent density ( $\rho)$ and porosity $(\varepsilon)$ of the studied sediment along profile no. 4

\begin{tabular}{lrr}
\hline $\begin{array}{l}\text { Sp. } \\
\text { No. }\end{array}$ & $\begin{array}{r}\rho \\
\left(\mathrm{kg} / \mathbf{m}^{3}\right)\end{array}$ & $\boldsymbol{\varepsilon}$ \\
\hline 21 & $\mathbf{1 5 7 3}$ & $\mathbf{0 . 2 3}$ \\
$\mathbf{2 2}$ & $\mathbf{1 8 2 4}$ & $\mathbf{0 . 2 2}$ \\
23 & $\mathbf{1 3 2 1}$ & $\mathbf{0 . 2 6}$ \\
24 & 1569 & $\mathbf{0 . 2 0}$ \\
25 & $\mathbf{1 7 4 3}$ & $\mathbf{0 . 2 0}$ \\
26 & $\mathbf{1 5 8 9}$ & $\mathbf{0 . 2 1}$ \\
27 & 1575 & $\mathbf{0 . 2 2}$ \\
Ave. & $\mathbf{1 5 9 9}$ & $\mathbf{0 . 2 2}$ \\
\hline
\end{tabular}


The porosity was estimated by slowly adding water, to the preceding used samples in the apparent specific gravity, and thoroughly shaked to reach just complete saturation with water. If there is an excess of water, it must be removed by absorption using the edge of a filter paper and weighed. The difference in weight is the volume of the pore spaces in the sands. Knowing that, the specific gravity of water is nearly 1 , therefore, the porosity of the dry sands at each location can be determined by dividing the water weight on the volume of the sample. The results are shown in Table (2).

\section{Heavy mineral contents}

The obtained $50 \mathrm{gm}$ representative samples are subjected to preparation by the removal of the silt and clay by washing in water and decantation then drying. The prepared samples are subjected to heavy liquid separation using Bromoform liquid in order to separate all the heavy minerals in the sink fraction (the heavy fraction). The resultant heavy fraction from each sample was weighed and their percentages in the original sample are calculated and shown in Table (3).

Table 3 : Total heavy minerals content in the study sediment

\begin{tabular}{|c|c|c|c|c|c|c|c|}
\hline \multicolumn{2}{|c|}{ Profile 1} & \multicolumn{2}{|c|}{ Profile 2} & \multicolumn{2}{|c|}{ Profile 3} & \multicolumn{2}{|c|}{ Profile 4} \\
\hline $\begin{array}{l}\text { Sp. } \\
\text { No. }\end{array}$ & $\begin{array}{r}\text { Total } \\
\text { heavy }(\%) \\
\end{array}$ & $\begin{array}{ll}\text { Sp. } \\
\text { No. }\end{array}$ & $\begin{array}{r}\text { Total } \\
\text { heavy }(\%) \\
\end{array}$ & $\begin{array}{l}\text { Sp. } \\
\text { No. }\end{array}$ & $\begin{array}{r}\text { Total } \\
\text { heavy }(\%) \\
\end{array}$ & $\begin{array}{l}\text { Sp. } \\
\text { No. }\end{array}$ & $\begin{array}{r}\text { Total } \\
\text { heavy }(\%) \\
\end{array}$ \\
\hline 1 & 39.66 & 8 & 35.05 & 15 & 26.29 & 21 & 27.41 \\
\hline 2 & 38.91 & 9 & 32.60 & 16 & 29.364 & 22 & 31.78 \\
\hline 3 & 24.80 & 10 & 20.33 & 17 & 23.04 & 23 & 23.02 \\
\hline 4 & 27.64 & 11 & 27.77 & 18 & 25.46 & 24 & 27.34 \\
\hline 5 & 24.92 & 12 & 31.85 & 19 & 28.22 & 25 & 30.36 \\
\hline 6 & 25.25 & 13 & 21.19 & 20 & 12.42 & 26 & 27.68 \\
\hline 7 & 20.23 & 14 & 10.56 & - & - & 27 & 27.45 \\
\hline Av. & 28.77 & & 25.62 & & 24.13 & & 27.86 \\
\hline
\end{tabular}

\section{Radiometric measurements}

Each representative samples weighing about $350 \mathrm{~g}$ was packed in a plastic container, well sealed and stored for about 30 days in order to measure the four radio-elements; $\mathrm{U}, \mathrm{Th}, \mathrm{Ra}$ and $\mathrm{K}$. The well sealing prevents the escape of radiogenic gases ${ }^{222} \mathrm{Rn}$ and ${ }^{220} \mathrm{Rn}$ and allows the in-growth of uranium ${ }^{238} \mathrm{U}$ and thorium ${ }^{232} \mathrm{Th}$ decay products to reach secular equilibrium. After attainment of secular equilibrium, each sample was measured in $\gamma$ ray laboratory for their $\mathrm{U}, \mathrm{Th}, \mathrm{Ra}$ and $\mathrm{K}$ contents using a high efficiency multi-channel analyzer of $\gamma$-ray spectrometer (NaI detector). This technique was carried out at the laboratory of $\gamma$-ray spectrometry of the Egyptian Nuclear Materials Authority (ENMA). Its probable measurement error was about $10 \%$, (Matolin, 1991).

Each sample was counted for 1000s. The radiometric measurement for the studied radionuclides was carried out through four energy regions of interest (ROIs). Since uranium and thorium are not $\gamma$-emitters, they are measured indirectly through the $\gamma$-ray photons emitted from their decay products, ${ }^{234} \mathrm{Th}(81-108 \mathrm{keV})$ for ${ }^{238} \mathrm{U},{ }^{212} \mathrm{~Pb}(221-273 \mathrm{keV})$ for ${ }^{232} \mathrm{Th}$, and radium they are measured from the $\gamma$-ray photon emitted by ${ }^{214} \mathrm{~Pb}(327-390 \mathrm{keV})$ whereas potassium was measured directly from the $\gamma$-ray photon emitted by ${ }^{40} \mathrm{~K}$ (1319-1471 keV). Consequently, they are expressed as equivalent $\mathrm{U}$ (eU), equivalent thorium (eTh) and equivalent radium (eRa). The chosen energy regions for $\mathrm{U}, \mathrm{Th}, \mathrm{Ra}$ and $\mathrm{K}$ are determined from the indicated energy lines of the spectra generated by means of laboratory uranium, thorium, radium and potassium reference standard samples provided by the IAEA (1989). The results are shown in Table (4).

\section{DISCUSSIONS OF THE RESULTS}

\section{Heavy Minerals and Terrestrial Radioactivity at Mastarouh}

In fact, the two heavy radioactive minerals, zircon and monazite are the main contributors for the radioactive phenomena of the Egyptian black sands, besides traces of uranothorite and xenotime. Also, there is a good correlation between the concentration of the two radioactive minerals and the total heavy mineral contents. Consequently, the variation of the concentration of the total heavy mineral contents varies the radioactivity level of the sediment. 
Table 4: Radioactivity concentration of ${ }^{238} \mathrm{U}$, ${ }^{232} \mathrm{Th},{ }^{226} \mathrm{Ra}{ }^{40} \mathrm{~K}$, and the total radioactivity concentration in the studied area

\begin{tabular}{|c|c|c|c|c|c|}
\hline $\begin{array}{l}\text { Sp. } \\
\text { No. }\end{array}$ & $\begin{array}{r}{ }^{238} \mathrm{U} \\
(\mathrm{Bq} / \mathrm{kg})\end{array}$ & $\begin{array}{c}{ }^{232} \mathrm{Th} \\
(\mathrm{Bq} / \mathrm{kg})\end{array}$ & $\begin{array}{r}{ }^{226} \mathrm{Ra} \\
(\mathrm{Bq} / \mathrm{kg})\end{array}$ & $\begin{array}{r}{ }^{40} \mathrm{~K} \\
(\mathrm{~Bq} / \mathrm{kg})\end{array}$ & $\begin{array}{r}\text { Total } \\
\text { Radioactivity } \\
(\mathrm{Bq} / \mathrm{kg})\end{array}$ \\
\hline \multicolumn{6}{|c|}{ Profile 1} \\
\hline 1 & 74.10 & 109.62 & 66.6 & 156.50 & 340.20 \\
\hline 2 & 86.45 & 81.20 & 44.4 & BDL & 167.70 \\
\hline 3 & 49.40 & 28.42 & 22.2 & 187.80 & 265.60 \\
\hline 4 & 61.75 & 60.90 & 33.3 & BDL & 122.70 \\
\hline 5 & 37.05 & 48.72 & 66.6 & 68.86 & 154.60 \\
\hline 6 & 86.45 & 60.90 & 33.3 & BDL & 147.40 \\
\hline 7 & 37.05 & 52.78 & 33.3 & 28.17 & 118.00 \\
\hline Ave. & 61.75 & 63.22 & 42.8 & 63.05 & 188.00 \\
\hline \multicolumn{6}{|c|}{ Profile 2} \\
\hline 8 & 74.10 & 105.60 & 66.6 & BDL & 179.70 \\
\hline 9 & 49.40 & 64.96 & 33.3 & 97.03 & 211.40 \\
\hline 10 & 24.70 & 40.60 & 22.2 & 50.08 & 115.40 \\
\hline 11 & 49.40 & 40.60 & 33.3 & 56.34 & 146.30 \\
\hline 12 & 37.05 & 40.60 & 11.1 & 115.80 & 193.50 \\
\hline 13 & 61.75 & 32.48 & 33.3 & 68.86 & 163.10 \\
\hline 14 & 37.05 & 24.36 & 22.2 & BDL & 61.41 \\
\hline Ave. & 47.64 & 49.88 & 37.6 & 55.45 & 153.00 \\
\hline \multicolumn{6}{|c|}{ Profile 3} \\
\hline 15 & 24.70 & 40.60 & 44.4 & 62.60 & 127.90 \\
\hline 16 & 49.40 & 73.08 & 11.1 & 25.04 & 147.50 \\
\hline 17 & 37.05 & 44.66 & 11.1 & 71.99 & 153.70 \\
\hline 18 & 37.05 & 12.18 & 33.3 & BDL & 49.23 \\
\hline 19 & 24.70 & 24.36 & 11.1 & BDL & 49.06 \\
\hline 20 & 37.05 & 16.24 & BDL & 65.73 & 119.00 \\
\hline Ave. & 34.99 & 35.19 & 18.5 & 37.56 & 107.70 \\
\hline \multicolumn{6}{|c|}{ Profile 4} \\
\hline 21 & 24.70 & 56.84 & 11.1 & 28.17 & 109.70 \\
\hline 22 & 49.40 & 36.54 & 11.1 & BDL & 85.94 \\
\hline 23 & 37.05 & 12.18 & 44.4 & 90.77 & 140.00 \\
\hline 24 & 49.40 & 44.66 & 22.1 & 56.34 & 150.40 \\
\hline 25 & 74.10 & 60.90 & 33.3 & 37.56 & 172.60 \\
\hline 26 & 49.40 & 12.18 & 11.1 & 78.25 & 139.80 \\
\hline 27 & 24.70 & 8.12 & 44.4 & 106.40 & 139.20 \\
\hline Ave. & 44.11 & 33.06 & 25.36 & 56.79 & 134.00 \\
\hline
\end{tabular}

Therefore, the concentration of the total heavy minerals including the two radioactive ones in the studied sands was found to vary from each location to the other, also the averages along the four profiles. The first profile displays heavy mineral contents from a minimum value of $20.32 \%$ to a maximum value of $39.66 \%$ with an average of $28.77 \%$. The second profile shows the three parameters as $10.56 \%, 35.05 \%$ and $25.62 \%$, respectively. The third profile has total heavy mineral contents varied from $10.56 \%$ to $39.66 \%$ with an average of $24.13 \%$. The last profile exhibits minimum heavy minerals contents of $23.02 \%$ and a maximum of $31.78 \%$ with an average of $27.86 \%$. The maximum average concentra- tion of the total heavy minerals was detected in the first profile, near the shore line, then gradually decreases in the two middle profiles and finally slightly increases in the fourth profile, near the North Africa International highway (Table, 3).

The variation of each of the averages of the total heavy mineral and that of the activity concentration of the four radio-nuclides; ${ }^{238} \mathrm{U}$, ${ }^{232} \mathrm{Th},{ }^{226} \mathrm{Ra}$ and ${ }^{40} \mathrm{~K}$ and the total activity concentration among the four profiles in the studied sands is graphically represented on Fig. (3). The average activity concentrations, in $\mathrm{Bq} / \mathrm{kg}$, of the four radio-nuclides, ${ }^{238} \mathrm{U},{ }^{232} \mathrm{Th},{ }^{226} \mathrm{Ra}$ and ${ }^{40} \mathrm{~K}$ and the total radioactivity, display the same behavior like the total heavy minerals except for ${ }^{232} \mathrm{Th}$. This is attributed to the presence of high correlation between the total heavy minerals including zircon and monazite and the radioactivity of the sediment measured from the air or from the ground (Wassef, 1973 and Meleik et al, 1978).

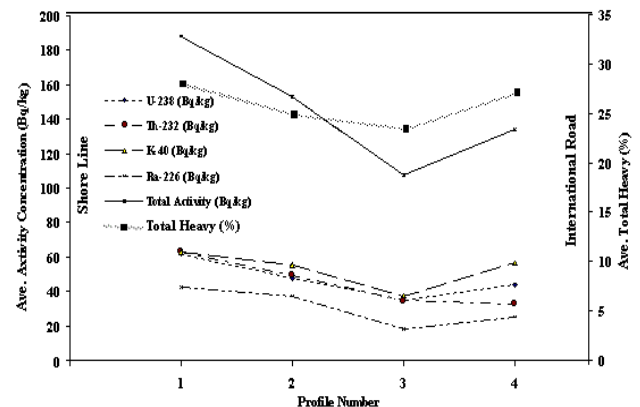

Fig. 3: Variation of the total heavy minerals and the activity concentrations in the sands at Mastarouh

The activity concentration, in $\mathrm{Bq} / \mathrm{kg}$, due to ${ }^{238} \mathrm{U}$ shows a minimum value of 37.05 , while the next three profiles exhibit the same minimum value of 24.70 . On the other hand, the maximum values of the four profiles are $86.45,74.10,49.40$ and 49.40 respectively. The averages of the activity concentration due to ${ }^{238} \mathrm{U}$ in the different profiles are $61.75,47.64$, 34.99 and 44.11 . The recorded minimum values for the activity concentration due to ${ }^{232} \mathrm{Th}$ are recorded at their western ends except the 
first profile with the values $28.40,24.36,8.12$ and 8.12 , respectively. Their maximum values are recorded at the western ends of the four profiles as follow: 109.62, 105.60, 40.60 and 56.84 . The average activity concentration due to ${ }^{232} \mathrm{Th}$ of the four profiles is $63.22,49.88$, 35.19 and 33.06 respectively.

The maximum activity concentrations in $\mathrm{Bq} / \mathrm{kg}$, due to radium are recorded at the western ends of the studied profile except the last profile. These maximum values are 66.6, 66.6, 44.4 and 44.4. While, the corresponding minimum values are 22.2, 11.1, below detection limit and 11.1, respectively. The average activity concentrations in the four profiles from profile one to profile four are $42.28,37.6,18.5$ and 25.36

The measured activity concentration emitted from ${ }^{40} \mathrm{~K}$ was found to vary from not detected in the sediment of the four profiles to maximum values of $187.70,97.03,63.73$ and 106.40 with the averages $63.50,55.40,37.56$ and 56.79 from profile one to profile four. The minimum values of the total activity concentration in $\mathrm{Bq} / \mathrm{kg}$ are $118.00,61.41,49.06$ and 85.94 while the adjacent maximum values are $340.20,24.40,153.70$ and 109.70 .

The average activity concentration of ${ }^{238} \mathrm{U}$ is higher than the world wide average $(40 \mathrm{~Bq} /$ $\mathrm{kg}$ ) along profiles 1,2 and 4 , while profile 3 exhibits low value. On the other hand, ${ }^{232} \mathrm{Th}$ activity concentration is higher than the mentioned figure on profiles 1 and 2 and low on the next two profiles. The activity concentration of ${ }^{40} \mathrm{~K}$ in the sands along the four profiles at Mastarouh reflects a particular characteristic of the sands originated from the beach deposits; below $400 \mathrm{~Bq} / \mathrm{kg}$, (UNSCEAR, 1993).

\section{Absorbed Dose}

The measured dose due to $\gamma$ ray in the field was found generally less than the calculated ones in the same site which may be attributed to the moisture content in the sediment. The measured moisture was found to vary from 0.09 to 012 with an average of 0.1 . Four mea- sured locations from seven ones show maximum dose of $37 \mathrm{nGy} / \mathrm{h}$.

The state of radioactive equilibrium indicates that it is possible to employ the obtained uranium concentration instead of radium concentration to estimate the external absorbed dose rates due to the external exposure to $\gamma$ rays, (Oyedele, 2006). The outdoor absorbed dose rates $\mathrm{D}$ due to terrestrial gamma rays at $1 \mathrm{~m}$ level above the ground are calculated according to the relation given by (UNSCEAR, 1993) as:

$\mathrm{D}\left(\mathrm{nGyh}^{-1}\right)=0.429 \mathrm{U}+0.666 \mathrm{Th}+0.042 \mathrm{~K} \ldots .$. (2)

where $\mathrm{U}$, Th and $\mathrm{K}$ are the activity concentrations of ${ }^{238} \mathrm{U},{ }^{232} \mathrm{Th}$ and ${ }^{40} \mathrm{~K}$ in $\mathrm{Bq} / \mathrm{kg}$, respectively.

By applying the measured activity concentrations of ${ }^{238} \mathrm{U},{ }^{232} \mathrm{Th}$ and ${ }^{40} \mathrm{~K}$ in the studied sands (Table 4), the calculated values of $D$ are shown in Table (5). The results show that the dose rate values vary from a minimum value of $20.50 \mathrm{nGy} / \mathrm{h}$ to a maximum value of $111.00 \mathrm{nGy} / \mathrm{h}$. The highest value was recorded on the western end of profile 1 near the shoreline while the lowest value was found at the eastern end of the fourth profile near the North Africa International Highway.

Table 5: Absorbed dose rate $\mathrm{D}$ at height of $1 \mathrm{~m}$ above the sand surface at Mastarouh area

\begin{tabular}{|c|c|c|c|c|c|c|c|c|c|}
\hline & \multicolumn{2}{|c|}{ Profile 1} & \multicolumn{2}{|c|}{ Profile 2} & \multicolumn{2}{|c|}{ Profile 3} & \multicolumn{2}{|c|}{ Profile 4} & \\
\hline & Sp. & D & Sp. & D & Sp. & D & $\mathrm{Sp}$ & D & \\
\hline & No. & (nGy/h) & No. & $(\mathrm{nGy} / \mathrm{h})$ & No. & $(\mathrm{nGy} / \mathrm{h})$ & $\begin{array}{ll}\text { No.. } \\
\text { nat }\end{array}$ & $(\mathrm{nGy} / \mathrm{h})$ & \\
\hline & 1 & 111.00 & 8 & 102.40 & 15 & 40.12 & 21 & 49.39 & $\bar{z}$ \\
\hline & 2 & 90.70 & 9 & 68.27 & 16 & 70.55 & 22 & 45.289 & \\
\hline & 3 & 48.00 & 10 & 39.58 & 17 & 48.48 & 23 & 27.79 & \\
\hline & 4 & 66.70 & 11 & 50.39 & 18 & 23.88 & 24 & 53.09 & $\Xi$ \\
\hline & 5 & 51.00 & 12 & 47.68 & 19 & 26.67 & 25 & 73.57 & 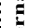 \\
\hline & 6 & 77.22 & 13 & 50.80 & 20 & 29.40 & 26 & 32.52 & 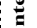 \\
\hline & 7 & 52.00 & 14 & 31.95 & -- & - & 27 & 20.50 & \\
\hline & Av. & 70.95 & & 55.87 & & 39.85 & & 42.35 & \\
\hline & Wor & He aver & $\mathbb{e}$ & ectrosce & IC & $1=60 n$ & & & \\
\hline
\end{tabular}

Generally, most of the recorded averages of the absorbed dose rate $\mathrm{D}$ are beyond the worldwide average. About three quarters of the obtained values are lower than the worldwide average for the absorbed dose rate. The average of the dose rate on profile 1 is 70.95 $\mathrm{nGy} / \mathrm{h}$. This value is higher than the worldwide average. This value decreases for the 
next three profiles and is less than the worldwide average. The averages of the absorbed dose rate $\mathrm{D}$ are behaved in the same manner as each of the total heavy minerals, the four radio-nuclides except thorium and the total radioactivity.

The population-weighted average is 59 $\mathrm{nGy} \mathrm{h}^{-1}$. The average values range from 18 to $93 \mathrm{nGy} \mathrm{h}^{-1}$. A typical range of variability for measured absorbed dose rates in air is from 10 to $200 \mathrm{nGy} \mathrm{h}^{-1}$. The population-weighted values give absorbed dose rate in air outdoor from terrestrial gamma radiation of $60 \mathrm{nGy}$ $\mathrm{h}^{-1}$, (UNSCEAR, 2000).

The estimated absorbed dose $D$ rate (nGy/ h) at $1 \mathrm{~m}$ above the ground show that the average value of $\mathrm{D}$ over profile no. 1 is higher than the worldwide value $(60 \mathrm{nGy} / \mathrm{h})$. However, the average value of the absorbed dose $D$ shows the same behavior as the activity concentrations over the four profiles at Mastarouh.

\section{External Effective Dose}

In the UNSCEAR 1993 report, the committee used $0.7 \mathrm{~Sv} \mathrm{~Gy}^{-1}$ for the conversion coefficient from absorbed dose in air to effective dose received by adults. Accordingly, the effective dose rate $\mathrm{E}_{\text {cal }}(\mathrm{nSv} / / \mathrm{h})$ at $1 \mathrm{~m}$ over the sands along the fourth profile studied at Mastarouh area can be obtained as follows:

$E_{\text {cal }}(\mathrm{nSv} / \mathrm{h})=\mathrm{D}(\mathrm{nGy} / \mathrm{h}) \times 0.7$

where $\mathrm{D}(\mathrm{nGy} / \mathrm{h})$ is the absorbed dose at $1 \mathrm{~m}$ over the sands over profile no. 4, Table (5).

The data in Table (6) compares the measured effective dose rate $E$ to the calculated one, $E_{\mathrm{cal}}$. From the table, the average value of $E$ is lower than the average value of $E_{\text {cal }}$. This is due to the fact that the water content in the sands at Mastarouh acts as a shield which attenuates the gamma rays emitted from the radio-nuclides in the sands and accordingly decreases the absorbed dose rate and the resulting effective dose rate $E$.
Table 6 : Comparison between the measured and calculated external effective dose rate over the sands along the fourth profile

\begin{tabular}{lrr}
\hline Sp. & $\begin{array}{r}\mathbf{E} \\
\text { No. }\end{array}$ & $\begin{array}{r}\mathbf{E}_{\text {Cal }} \\
(\mathbf{n S v} / \mathbf{h})\end{array}$ \\
\hline $\mathbf{2 1}$ & $\mathbf{3 7} / \mathbf{h})$ \\
$\mathbf{2 2}$ & 7 & $\mathbf{3 4 . 5 7}$ \\
$\mathbf{2 3}$ & $\mathbf{3 1 . 7 0}$ \\
$\mathbf{2 4}$ & $\mathbf{2 2}$ & $\mathbf{1 9 . 5}$ \\
$\mathbf{2 5}$ & $\mathbf{3 7}$ & $\mathbf{5 1 . 5}$ \\
$\mathbf{2 6}$ & 37 & $\mathbf{2 2 . 7 6}$ \\
$\mathbf{2 7}$ & 7 & $\mathbf{1 4 . 3 5}$ \\
Av. & $\mathbf{2 6}$ & $\mathbf{3 0 . 2 1}$ \\
\hline
\end{tabular}

\section{Radon Flux}

The main mechanism for entry of radon into the atmosphere is molecular diffusion. From equation (1) and taking into consideration the previously mentioned dimensions for the hole, the radon flux (J) from the sands into the atmosphere at a certain location is obtained as follows:

$$
\mathrm{J}=2.05 \times 10^{-6} \mathrm{xC}_{\mathrm{Rn}}\left(\mathrm{Bq} \mathrm{m}^{-2} \mathrm{~s}^{-1}\right) \text {. }
$$

where $\mathrm{C}_{\mathrm{Rn}}\left(\mathrm{Bq} / \mathrm{m}^{3}\right)$ is the radon gas concentration in the hole at each location.

The resultant values of the radon flux from the sands into the atmosphere of the studied area are shown in Table (7). From the Table, radon flux at Mastarouh has an average of $2.48 \times 10^{-3}\left(\mathrm{~Bq} \mathrm{~m} \mathrm{~m}^{-2} \mathrm{~s}^{-1}\right)$. This value is nearly ninth of the worldwide average of $2.2 \times 10^{-2}$ $\left(\mathrm{Bq} \mathrm{m}^{-2} \mathrm{~s}^{-1}\right.$ ), (UNSCEAR, 2000).

Table 7: Pore radon concentration $\mathrm{C}_{\mathrm{Rn}}$, radon flux $\mathrm{J}$, porosity $\varepsilon$ and emanation coefficient $\mathrm{f}$ of the sands at Mastarouh

\begin{tabular}{|c|c|c|c|c|}
\hline $\begin{array}{l}\text { Sp. } \\
\text { No. }\end{array}$ & 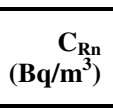 & $\begin{array}{r}\mathrm{J} \\
\left(\mathrm{Bq} \mathrm{m}^{-2} \mathrm{~s}^{-1}\right) \\
\mathrm{x10}^{-3}\end{array}$ & $\varepsilon$ & $\begin{array}{r}(\%) \\
f \\
\times 10^{-2} \\
\end{array}$ \\
\hline 21 & 917 & 1.88 & 0.23 & 6.66 \\
\hline 22 & 975 & 2.00 & 0.22 & 6.03 \\
\hline 23 & 1369 & 2.81 & 0.26 & 3.08 \\
\hline 24 & 2057 & 4.22 & 0.20 & 7.24 \\
\hline 25 & 1782 & 3.65 & 0.20 & 3.75 \\
\hline 26 & 1263 & 2.59 & 0.21 & 8.85 \\
\hline 27 & 111 & 0.23 & 0.22 & 0.20 \\
\hline Av. & 1211 & 2.48 & 0.22 & 5.11 \\
\hline
\end{tabular}




\section{Emanation Coefficient}

For a porous mass of homogeneous material semi-infinite in extent, the flux density of radon at the surface of dry sands, considering the fraction of radon atoms generated from radium decay that are released from a rock or soil into the pore space is defined as the radon emanation coefficient. It is calculated by the expression given by the UNSCEAR, (2000):

$\mathrm{J}={ }^{226} \operatorname{Ra} \lambda \mathrm{f} \rho(1-\varepsilon) \mathrm{L} \ldots\left(\mathrm{Bq} \mathrm{m}^{-2} \mathrm{~s}^{-1}\right)$

where: ${ }^{226} \mathrm{Ra}$ : is the radioactivity concentration of ${ }^{226} \mathrm{Ra}$ in the sands $\left(\mathrm{Bq} \mathrm{kg}^{-1}\right), \lambda$ : is the decay constant of ${ }^{222} \mathrm{Rn}=2.1 \times 10^{-6} \mathrm{~s}^{-1}$, $\mathrm{f}:$ is the emanation coefficient of the sands, $\rho:$ is the sand density $\mathrm{kg} / \mathrm{m}^{3}, \varepsilon$ $:$ is the effective porosity of the sands, $\mathrm{L}$ : the diffusion length that equals to $1 \mathrm{~m}$.

Substituting the values of the variables in equation (5) from Tables $(2 \& 4)$, and substituting the values of $\mathrm{J}$ obtained by equation (4), the values of the emanation coefficient $f$ at each location along the fourth profile is obtained and shown in Table (7). From the table, the density of the dry collected sands from Mastarouh is $1599 \mathrm{~kg} / \mathrm{m} 3$, with an effective porosity of 0.22 have an average emanation coefficient of 0.0511 or $5.11 \%$.

Comparing the values of the emitted radioactivity of the black sands at Mastarouh area to that of Rasheed, Barakat (2008), indicates that the $10 \%$ water content in the sands at Mastarouh decreased the effective porosity of the sands at the latter area while increased the emanation coefficient of these sands. Water content increases the volume and the surface area of the sand grains and accordingly the emanation coefficient of these sands.

\section{CONCLUSIONS}

The maximum recorded value for the average content of the total heavy minerals was detected in the first profile, near the shore line, then gradually decreases in the two middle profiles and slightly increases in the fourth profile, near the North Africa International high way. The average activity concentrations of the four radio-nuclides, ${ }^{238} \mathrm{U},{ }^{232} \mathrm{Th},{ }^{226} \mathrm{Ra}$, ${ }^{40} \mathrm{~K}$ and the total activity concentration, display the same behavior like the total heavy minerals. This is attributed to the presence of high correlation between the total heavy minerals including zircon and monazite and the radioactivity of the sediment.

The absorbed dose rate values, in $n G y / h$, are generally less than the calculated ones. They vary from a minimum value of 20.50 $\mathrm{nGy} / \mathrm{h}$ to a maximum value of $111.00 \mathrm{nGy} / \mathrm{h}$. The highest value was recorded on the western end of profile 1 near the shoreline while the lowest value was found at the eastern end of the fourth profile near North Africa International Highway. About three quarters of the absorbed dose rate (D) averages are beyond the worldwide average and one quarter is higher than the mentioned worldwide average for the absorbed dose rate. The average of the absorbed dose rate on the first profile is higher than the worldwide average then it decreases for the next three profiles to be less than the worldwide average.

The radon flux at Mastarouh has an average of $2.48 \times 10^{-3}\left(\mathrm{~Bq} \mathrm{~m} \mathrm{~m}^{-2} \mathrm{~s}^{-1}\right)$. This value is much lower than the worldwide average of $2.2 \times 10^{-2}\left(\mathrm{~Bq} \mathrm{~m}^{-2} \mathrm{~s}^{-1}\right)$. The average value of the emanation coefficient of the sands at Mastarouh is 0.0511 or $5.11 \%$.

The activity concentrations of all the studied radio-nuclides in the beach sands due the north of the North Africa International Highway at Mastarouh area are comparable to the typical worldwide concentrations. Water content in the sands at Mastarouh decreases the effective dose rate due to the terrestrial radioactivity and increases the emanation coefficient of these sands. However, the average value of the effective dose rate due to the sands at Mastarouh is lower than the world wide average indicating a safe area for any probable resident projects.

\section{RERERENCES}

Abdel-Razek,Y.A.; Said, A.F.; Hassan, S.F., and Elsayed, M. A., 2012.On The Occu- 
pational Radiation Exposures During Mineral Separation Processes At Rasheed And Abu Khashaba Facilities. Internal report N.M.A.,IRS-1/2012, Cairo, Egypt.

Barakat, M.G., 2004. Sedimentological studies and evaluation of some black sands deposition on the northern coast of Egypt. M. Sc. Thesis, Fac. Sci., Alexandria Univ.

Barakat, M.S.A., 2008. Radioactivity and Radon Emanation Measurements in Some Natural Samples. M. Sc. Thesis, Fac. Sci., Menoufia Univ., Menoufia, Egypt, 86p.

Dabbour, G.A., 1992. Heavy minerals content and its relation to apparent specific gravity. Mans. Sci. Bull., special Issue,

International Atomic Energy Agency, IAEA, 1989. Construction and use of calibration facilities for radiometric field equipment. IAEA Technical Reports Series No. 309, IAEA, Vienna.

Matolin, M.,1991. Construction and use of spectrometric calibration pads for laboratory $\gamma$-ray spectrometry, NMA, Egypt. Report on Project EGY/4/030- IAEA to the Government of the Arab Republic of Egypt, 14p.

Meleik, M.L.; Fouad, K.M.; Wassef, S.N.; Ammar, A.A., and Dabbour, G.A.,1978. Aerial and ground radiometry in relation to the sedimentation of radioactive minerals of the Damietta beach sands, Egypt. Eco. Geol., 73, $1738-1748$.

Nasr, A. S., 2012. Environmental and Biophysical Consideration of Radioactive Elements in Processes of Separation and Concentration of Black Sand Products in Egypt. M.Sc. Thesis, Fac. Sci., Cairo University, $85 \mathrm{p}$.

Oyedele, J. A.,2006. Measurements of the natural radioactivity at the international high energy stereoscopic system (HESS) project in Southern Africa. Appl. Radait. And Isot. 64,686-688.

Tompkins, R.W.,1978. Radiation In Uranium Mines. Part 1, CIM Bull., 75, No. 847,

UNSCEAR, 1993. Exposures from natural sources of radiation. United Nations Scientific Committee on the Effects of Atomic Radiation. Report to the General Assembly, Annex A, 33-89.

UNSCEAR, 2000. Exposures from natural sources of radiation. United Nations Scientific Committee on the Effects of Atomic Radiation. Report to the General Assembly, Annex A, 83-156.

Wassef, S.N.,1973. Distribution of monazite in the black sands of Rosetta, Damietta and its conditions of sedimentation. Ph. D. Thesis, Fac. Sci., Ain Shams Univ., Cairo.

Zaghloul, Z.M.,1959. The radioactivity of zircon, zircon specific alpha $\alpha$-particle radioactivity and the grain size effect. J. Geol. U.A.R., 3, 159-165.

Zaghloul, Z.M.,1960. Note on the occurrence of uranothorite and radioactive zircon in the black sands of Rosetta. J. Geol. U.A.R., 4, 89 - 91.

Zaghloul, Z.M.; Abd Rahim A.M., and Abdalla, A.,1961. Measurement of total alpha particle radioactivity of mineral grains. $\mathrm{J}$. Geol. U.A.R., 5, 91-102.

Zaghloul, Z.M., and Kamel K.E.,1965. The mineralogical and petrographical features of monazite from the black sands of Rosetta. J. Geol. U.A.R., 9,17-31.

Zaghloul, Z.M., and Kamel, K.,1966. Mineralogical and petrographical features of zircon of the black sands of Rosetta: Bull. Inst. Desert, Egypt.,16, No. 1,1 -17. 


\section{تأثير بعض الخواص الفيزيائية للرمال السوداء على التعرضات الإشعاعية

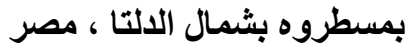

$$
\text { يس عبد العظيم عبد الرازق و عبد العليم أبو دياب و عنتر فهمى بخيت }
$$

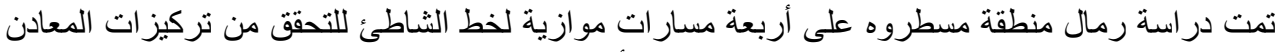

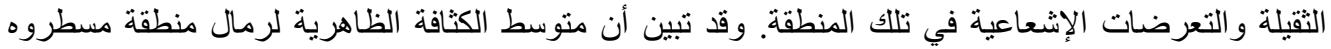

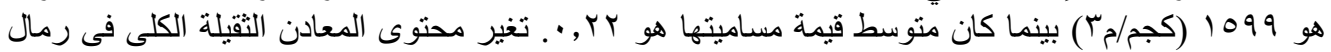

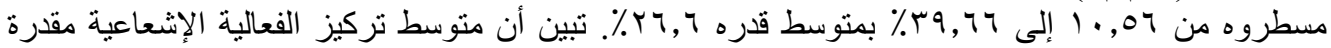

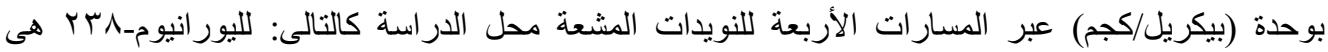

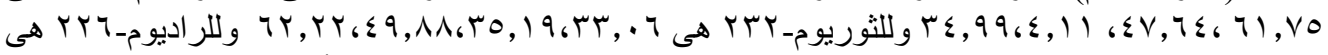

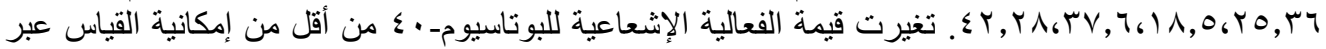

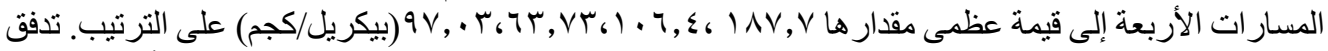

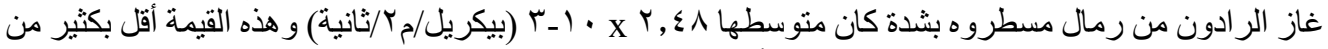

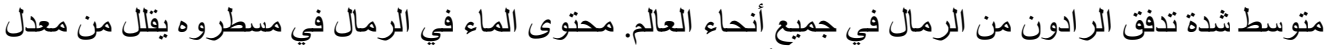

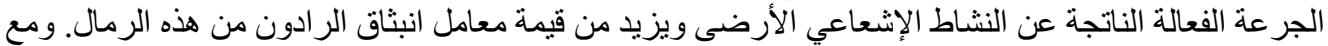

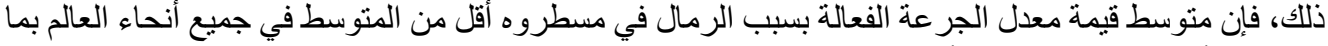
يشير إلى أن تلاك المنطقة آمنة لأية مشاريع سكنية محتملة. 